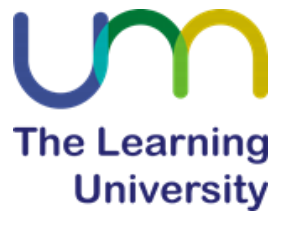

Icssh, 1(1), 2017

PROCEEDINGS

The Ist International Conference on Sports Science and Health

\title{
ECONOMIC EMPOWERMENT FOR FORMER LEPROSY PATIENT THROUGH CULTIVATION OF MOSQUITO REPELLENT PLANTS
}

\author{
Puri Ratna Kartini, Universitas PGRI Madiun \\ Ani Sulistyarsi, Universitas PGRI Madiun \\ Arum Suproborini, Universitas PGRI Madiun \\ Email: puri.ratn@yahoo.com
}

\begin{abstract}
Leprosy is an infectious disease which tends to end up with disability and leads to problems in terms of health and economy. Thus, there should be an effort to empower the former leprosy patients. The cultivation of mosquito repellent plants is a new methode to prevent the incidence of DHF which is safer for health and can also provide benefit. Considering that Indonesia is an endemic country of DHF and leprosy, this effort can be a correct step to tackle two problems in health at once.
\end{abstract}

Keywords: Cultivation, Empowerment, Leprosy

Leprosy is one of global health problems. It's been recorded about 15-20 million people in the world is a leper. The major endemic areas of the disease are Africa, America, Southeast Asia, the Eastern Mediterranean, and the Western Pacific (Kamal, 2015). Based on World Health Organization (WHO) data, Indonesia is one of the countries with the highest number of leprosy patients in the world, which is 16,856 cases. So in 2013, Indonesia ranks the third of the largest cases of leprosy after India (134,752 cases) and Brazil (33,303 cases) (WHO, 2014). Meanwhile, according to the Director General of Disease Prevention and Control of the Ministry of Health, the prevalence rate of leprosy patients in Indonesia in 2015 is 0.78 per 10,000 population, so the number of registered patients is about 20,160 cases. There are 14 provinces in Indonesia with prevalence rate $>1 / 10.000$ population, namely Banten, Central Sulawesi, Aceh, East Java, South Sulawesi, West Sulawesi, North Sulawesi, Gorontalo, Maluku, North Maluku, Papua, West Papua and North Kalimantan (P2P Ministry of Health RI, 2015).

Leprosy is a chronic infection caused by Mycobacterium Leprae. The germs in the early phase will attack the peripheral nervous system, then the skin, eyes, muscles and bones that tend to end up with disability. WHO estimates $25 \%$ of leprosy patients experience disability. In Indonesia the proportion of leprosy patients defects by $10.4 \%$ (Purwanto, 2013). In addition to the bad stigma in the community, the flawed condition experienced by most former leprosy sufferers can lead to other problems of economic dependence. In other words, leprosy is a contagious disease that affects not only the medical but also the social and economic aspects (Purwanto, 2013).

These problems can certainly affect the quality of development of Indonesian society or more commonly called the Human Development Index (HDI). Because one of the important indicators in the HDI is the economic index as measured by real per capita income. Leprosy generally affects the productive age group of 25-35 years. As a result these age groups can become economically uneconomical.

Therefore, various efforts should be made in order to regenerate economic independence in former leprosy patients. Efforts to regenerate economic independence in former leprosy patients can be through various activities of economic empowerment. Types of economic empowerment in former leprosy patients are usually activities that do not require special skills and education, so the former leprosy sufferers who incidentally 


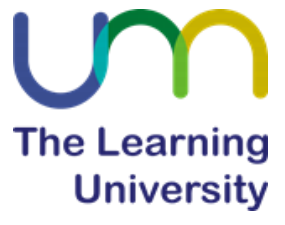

Icssh, 1(1), 2017

PROCEEDINGS

The Ist International Conference on Sports Science and Health

have a low level of education can do it. One of the empowerment activities that can be done by former lepers is through the cultivation of plants.

\section{DISCUSSION}

\section{Mosquito repellent cultivation}

Indonesia is one of the third most leprosy countries in the world, also one of the endemic countries of Dengue Hemorrhagic Fever (DBD). From 1968 to 2011, WHO noted Indonesia as the country with the highest dengue fever case in Southeast Asia (WHO, 2012). Until now dengue disease in Indonesia is still one of the public health problems. Based on the report of Research and Development Center of the Ministry of Health of the Republic of Indonesia, recorded cases of dengue in Indonesia in 2015 as many as 129,650 cases, increased from 99.499 cases in 2014 (Kemenkes RI, 2015).

DHF control program in Indonesia is implemented through 2 activities, namely PSN through 3M plus to control Aedes aegypti mosquito larvae and fogging activities to control adult mosquito (Kartini, 2017). Today there have been many studies that prove the side effects of using chemicals on fogging for health. Insect poisons used for fogging are organophosporester insecticidal groups such as malation, sumithion, fenithrothion, perslin, and others. The most common and often used is malation. Insecticide malation has been used by the government in fogging since 1972 in Indonesia. However, for fogging with fog machine, malation must be diluted with the addition of diesel or kerosene (DHO Cirebon, 2015).

Fogging is highly polluting the environment and ultimately contaminates humans. In addition, the fogging action is expensive with a result that is not so significant even will make mosquitoes become resistant (immune and not dead due to fogging). From the Journal of Epidemiolgy in 1992 also examined the relationship between exposure to malation with the incidence of gastrointestinal disorders (gastrointestinal tract). It was found that pregnant women exposed to malation had a 2.5 times greater risk of their child suffering from gastrointestinal disorders (DHO Cirebon, 2015).

Other problems that have also been studied are exposure to this malation resulting in kidney failure, newborn disorders, gene and chromosomal damage to the baby in utero, lung damage, and decreased immune system. Malation is also thought to have a role against 28 disorders, ranging from sperm motion disorders to hyperactivity in children. Not to mention the dangers of diesel fuel that is the soluble material. The burning results bind hemoglobin $(\mathrm{Hb})$ in the blood rather than oxygen. In addition, the burning toxins result in pneumonia (cured 6-8 weeks), blockage of bronchioli (may die 35 weeks), as well as excessive irritation and mucus production in the airway (DHO Cirebon, 2015).

Long-term hazards of pesticides including insecticides in the treatment of dengue can cause chronic effects on the body, including the nervous system, severe memory problems, difficulty concentrating, personality changes, paralysis, loss of consciousness and coma. In the stomach of vomiting, abdominal pain, diarrhea. It can also have adverse effects on the immune system and hormonal balance. The long-term effects that may be caused by these toxins will be carcinogenic, mutagenic (genetic damage for future generations), teratogenic (birth defects from mothers who are poisoned), and residual residue is harmful to consumers. This is caused by fogging materials containing substances that are toxic. The materials are sprayed in the form of smoke to people's homes will be very dangerous for all family members, especially children and toddlers if inhaling (DHO Cirebon, 2015).

Thus it is necessary to have a new method that is safer for health to prevent mosquito bites DBD vector. One of them by utilizing natural chemicals contained in 
plants. Today many studies have found that certain types of plants contain organic chemical compounds that produce odors / scents that are not preferred by mosquitoes so they can be used as a base material in the manufacture of anti-mosquito / repellent. For example lavender, citronella, geranium, etc. Lavender in general has been widely used in making repellent because the aroma is not preferred by mosquitoes. The content of organic chemicals contained in geranium, geraniol, citronelol proved to affect the sensory nerve of insects. While the content of organic chemical compounds in citronella citron is sitral can repel insects especially mosquitoes (Melanie, 2012).

Utilization of mosquito repellent plants can be applied in the simplest way, namely by planting in pots and placed outside or in the room where we do daily activities. For children who spend a lot of time in the school environment, this mosquito repellent can be placed in the classroom or in the schoolyard so as to expel and ward off mosquitoes as children learn in the room and play in the schoolyard (Melanie, 2012) . Cultivation of this plant is also quite easy that can be done by stem cuttings, grafts, spreading shoots saplings and by seeding seeds. Some examples of species of mosquito repellent plants that can be cultivated include:

\section{Lavender flower (Lavandula latifolia)}

Lavender included in the lamiaceae tribe that has 25-30 species. This flower has long been known as anti mosquito because it contains linalool and linalyl acetate. The use of levender flowers for mosquito repellent is to put flowers and plants in the room. This flower has enough economic value that is the price of plant per polybag is Rp. 10,000 Rp. 15.000 so the opportunity to be cultivated.

The lavender plant is the highest shrub type $1 \mathrm{~m}$ of parallel leaf, the bluish purple flowers on the tip of the leaf. Its spread includes wild plants in several places in Indonesia. The place grows at an altitude of 500-1300 dpl. Propagation can be done vegetatively through stem cuttings and generatively through seeds. Propagation of lavender plants usually use seeds that are old and healthy and then seeded. If it has grown, it is transferred into polybags. When it reaches $15-20 \mathrm{~cm}$ can be moved into pots or planted in the yard. Picture of lavender flowers can be seen in Figure 1Emigarden, 2009).

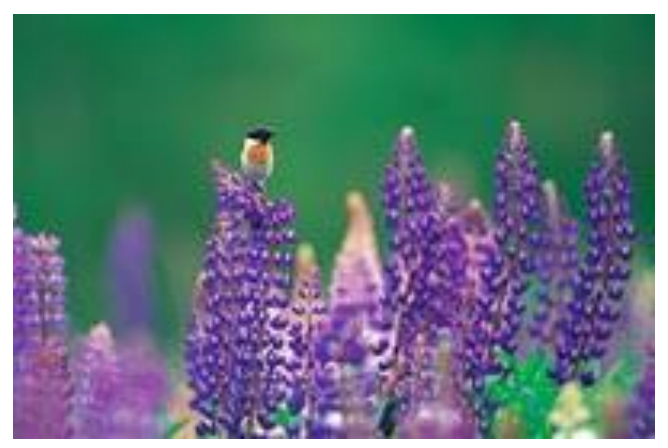

Figure 1. Lavender

\section{Zodia (Evodia suaveolensi)}

This plant belongs to the Rutaceae family and contains evodiamine and rutaecarpine substances. According to Research Institute of Spices and Medicinal plants (Balitro). This plant, if distilled, contains linalool $46 \%$ and $13.25 \%$ apinene. Zodia is able 


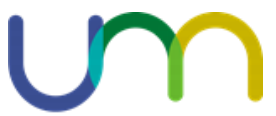

The Learning University

to dispel mosquitoes for 6 hours with protection of more than $70 \%$ (Agus Kardinan, 2001).

These plants can be planted in pots and can be used as indoor plants and can be planted outdoors. This plant is also easily cultivated by way of cuttings of twigs and with the seeds. If these plants have flowered and produce seeds then these old seeds will fall around the plant and produce new plants. The initial phase of multiplication with seeds requires special attention for example avoided from direct sunlight. This plant is more suitable if placed in a cold area. Images of zodia can be seen in figure 2.

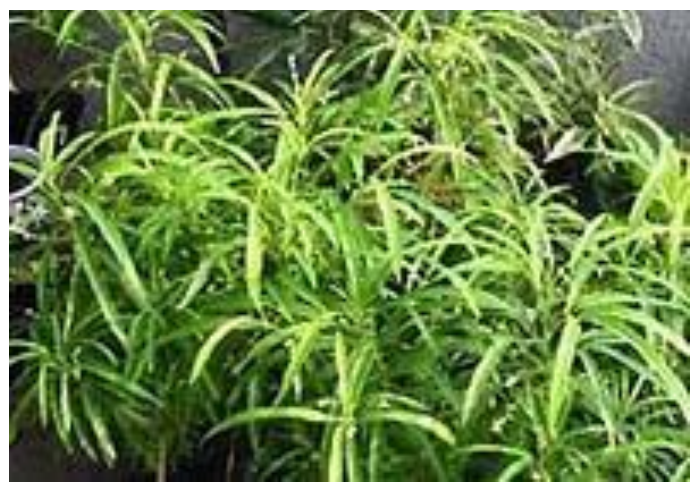

Figure 2. Zodia

\section{Geranium (Pelargonium citrosa)}

This plant contains the aroma of citronella and geraniol which is one type of aromatic compound so easily spread the air around (Agus Kardiman, 2001). In addition, in geranium plants are also contained geraniol senayawa able to repel mosquitoes. This plant can be used as an anti-mosquito plant because it smells distinctive and fragrant. This plant is a green leafy shrub that resembles anchors and edges of jagged leaves.

How to cultivation of this plant is by way of cuttings tillers. Rarely planted in pots because most of these plants are planted outdoors (outdoor plant). This plant can function as anti-mosquito is by the way taken the leaves and placed in the room as an aroma therapy. The image of Geranium can be seen in Figure 3.

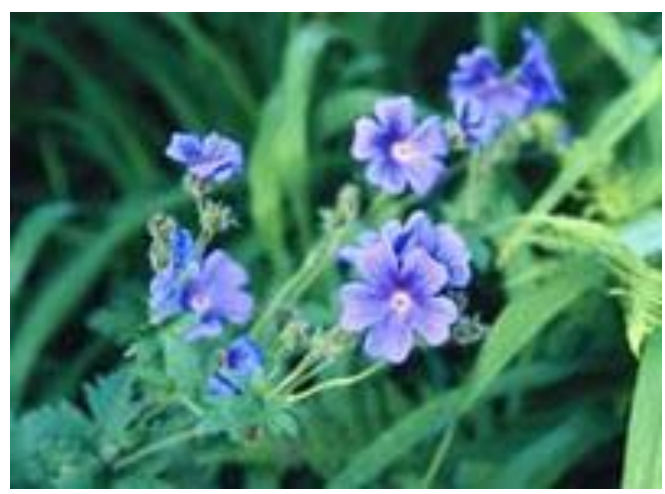

Figure 3. Geranium

\section{Citronella Citronella (Cymbopogon nardus)}

Citronella fragrance is included in the tribe of grasses. This plant has a distinctive aroma containing geraniol, methylheptenone, terpen-terpen, terpen-alcohol, organic acids 


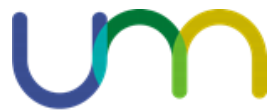

The Learning University

and the main content is citronellal. Sitronelal has properties as contact poison that can cause death from lack of fluids. Sitronelal usually used as raw material for mosquito repellent lotion (Agus Kardinan, 2001).

Chemical components in citronella oil are quite complex, but the most important components are sitronellal and geraniol. The chemical component of the main constituents of citronella oil is not fixed, and depends on several factors. Citronella leaves can be directly used as an anti-mosquito by burning these plants directly or lemongrass oil can be mixed on aroma candle making therapy (Suprianto, 2008).

Citronella fragrance can be propagated by separation of seedling cuttings. Cuttings are obtained by breaking large clumps but not beruas. Some of the leaves to be propagated are cut or reduced to $3-5 \mathrm{~cm}$ from the leaf midrib. Some roots are also kipotong and left to $2.5 \mathrm{~cm}$. The cut lemongrass can be grown in the yard or in the yard of the house. Treatment of this perfumed lemon grass is watered daily. Citronella plant can be seen in Figure 4.

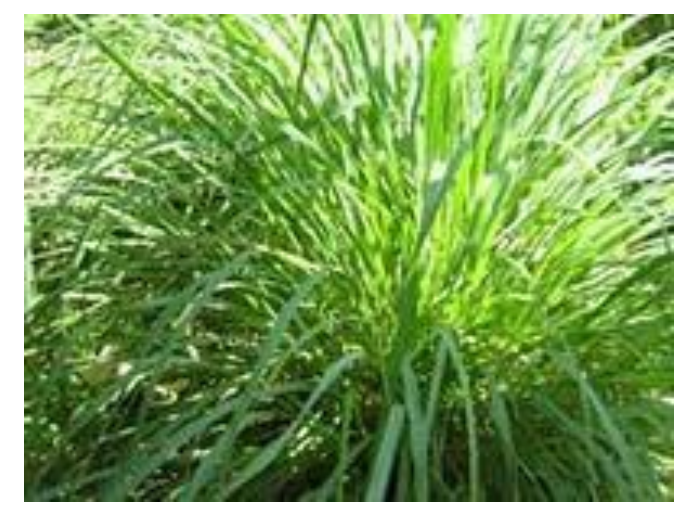

Figure 4. Citronella

\section{Rosemary Flower (Rosmarinus officinalis)}

This plant is included in lamiaceae tribes such as lavender. The aroma resembles the oil of telon so it can function as anti mosquito. Resemary flowers are purple and small size, needle-shaped but soft and have a length of $2-2.5 \mathrm{~cm}$. This plant can grow nicely even though it is placed indoors. In order for this plant to grow properly should be positioned close to the window to obtain adequate sun (Agus Kardinan, 2001).

Rosemary is one of the plants that belong to aromatic ta-naman, because it has a distinctive aroma. Its essential oil, often called quita essenta, contains karnosol, rosmasol, isorosmasol, epirosmasol, rosmaridifenol and rosmariquinon. The chemical compounds contained in the essential oils often used as insect repellent include sineol, camphor, camphene, linalool, limeon, borneon, mir-cene, terpineol and caryophyllene (Agus Kardinan, 2007)

Cultivation of this plant can be done by stem cuttings, grafting. These plants can grow in pots or can grow on the ground directly because the plant is resistant to pests and diseases. Terms of growing this plant is enough water and sunlight. The picture of rosemarry flowers can be seen in figure 5 . 


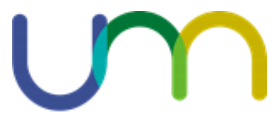

The Learning University

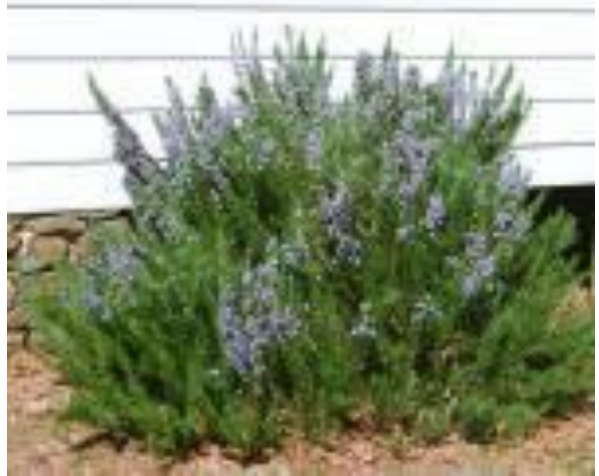

Figure 5. Rosemary

\section{Mosquito repellent cultivation as an effort to empower the economy of leprosy patients}

Empowerment by language comes from the word power which means power, process, way, empowerment (Language Center of Ministry of National Education, 2002). Empowerment is an effort to build people's power by encouraging, motivating and awakening awareness of their potential and working to develop it. Empowerment is directed to improve people's economy productively so as to generate high added value and greater income. Community economy is all economic activities and efforts of the community to meet their basic needs (clothing, food, shelter, health and education). Thus it can be understood that the economic empowerment of society is an effort to improve the ability or potential of the community in economic activities to meet the needs of life and improve their welfare and can potentially in the process of national development.

Mosquito repellent cultivation is one of the empowerment efforts that can be applied to the group of former lepers. Because these activities do not require special skills and education so easy to be done by former leprosy patients who in fact come from a community group with low education level. In addition, most of these mosquito repellent plants can mostly serve as an ornamental plant so much in demand if the community cultivated and treated well. In other words, this mosquito repellent plant also has economic value and is a requirement factor about anti-mosquito drugs that are safe for health and the environment so that this mosquito repellent plants worth to be cultivated. The cultivation of anti mosquito plants is expected to provide double benefits as a decorative plant that can be commercialized and as anti mosquito plants. Thus the economic empowerment of former leprosy patients through mosquito repellent cultivation can be a strategic step in solving two health problems, namely leprosy and dengue in endemic areas.

\section{CONCLUSION}

Mosquito repellent plants in addition to beneficial in preventing the incidence of DHF, is also an ornamental plant that much preferred by the community. So if it's cultivated properly can provide selling points. Besides it, the steps of cultivation of mosquito repellent plants is very easy and does not require a certain education or skills, so it can be done by former leprosy patients though. According to explanation above, it can be concluded that mosquito repellent cultivation is a strategic step to solve two health problems at once in the endemic areas of DHF and leprosy. 


\section{REFERENCES}

Agus, Kardinan. 2001. Mengenal Lebih Dekat Tanaman Pengusir dan Pembasmi Nyamuk. Jakarta: Agromedia.

Agus, Kardinan. 2007. Daya Tolak Tanaman Rosemarry (Rosmarinus officinalis) Terhadap Lalat (Musca domestica). Bul. Littro. Vol. XVIII No. 2, 2007, 170 - 17.

Depkes RI. 2015. Profil Kesehatan Indonesia. Depkes RI. Jakarta.

http://www.depkes.go.id/resources/download/pusdatin/profil-kesehatan-indonesia/profilkesehatan-Indonesia-2015.pdf (diakses pada 7 September 2017).

Dinkes Kabupaten Cirebon, 2015. Bahaya Fogging. Buletin mingguan EWARS SeksiPengawasanPenyakitBidang P2P Tahun 2015

https://surveilanskabcirebon.files.wordpress.com/2015/03/buletin-ewars-minggu-9bahaya-fogging.pdf (diakses pada 7 September 2017).

Emigarden. 2009. Memakai Tanaman untuk Mengusir Nyamuk Alami dan Ampuh. www.artikelwanita.com (diakses pada 7 September 2017).

Kemenkes RI, 2017. 24 Indikator Kesehatan Dalam IPM. Jakarta.

http://www.depkes.go.id/pdf.php?id=1337 (diakses pada tanggal 7 September 2017).

Marwati, Siti. 2011. Pengenalan dan Pelatihan Budidaya Tumbuhan Anti Nyamuk Di Kelompok PKK Kricak Kidul Tegalrejo Yogyakarta. Naskah Publikasi Seminar. Yogyakarta: Jurusan Pendidikan Kimia FMIPA UNY.

Purwanto, Heri. 2013. Cara Penemuan Penderita Kusta Baru dan Tingkat Kecacatan di Provinsi Lampung. Jurnal Kesehatan, Volume IV, Nomor 2,Oktober 2013, hlm $371-380$

https://www.google.co.id/url?sa=t\&rct=j\&q=\&esrc=s\&source=web\&cd=4\&cad=rja\&uac $\mathrm{t}=8 \&$ ved=0ahUKEwjJ6c2U_5HWAhVFto8KHRdPDVYQFgg9MAM\&url=http\% 3A\%2F\%2Fpoltekkestjk.ac.id\%2Fejurnal\%2Findex.php\%2FJK\%2Farticle\%2Fdo wnload\%2F80\%2F73\&usg=AFQjCNGIqETx85ft9EWNC6UryAk7Wn7T-w (diakses pada tanggal 7 September 2017).

Pusat Bahsa Departemen Pendidikan Nasional. 2002. Kamus Besar Bahasa Indonesia. Jakarta: Balai Pustaka.

Suprianto. 2008. Potensi Ekstrak Sereh Wangi (Cymbopogon nardus) Sebagai Anti Streptococcus mutans. Skripsi. Bogor: FMIPA IPB.

WHO. 2014. The Weekly Epidemiological Record (WER) Vol. 2014, No. 36, 2014, 89, 389-400.

http://www.who.int/wer/2014/wer8936.pdf (diakses pada tanggal 7 September 2017). 